\title{
The Breakthrough Diagnosis of Angiomyolipoma in a Histopathological study of Testicular lesions - A Single Centre Experience
}

\author{
Dr. K Suhasini ${ }^{1}$, Dr. Karthik Kasireddy ${ }^{2 *}$, Dr. Syeda Khadija Fatima ${ }^{2}$, Dr. Bhavani M $^{3}$ \\ ${ }^{1}$ Post Graduate Student, Kamineni Institute of Medical Sciences, Narketpally, Telangana, 508254, India \\ ${ }^{2}$ Assistant Professor, Department of Pathology, Kamineni Institute of Medical Sciences, Narketpally, Telangana 508254, India \\ ${ }^{3}$ Professor and HOD, Department of Pathology, Kamineni Institute of Medical Sciences, Narketpally, Telangana 508254, India
}

DOI: $\underline{10.36348 / \mathrm{sjpm} .2020 . \mathrm{v} 05 \mathrm{i} 02.018}$

| Received: 19.02.2020 | Accepted: 26.02.2020 | Published: 29.02.2020

*Corresponding author: Dr. Karthik Kasireddy

\section{Abstract}

Background: Germ cell Tumours (GCT) of testis accounts for majority of the testicular tumours while Non germ cell tumours of testis are generally rare. Angiomyolipoma (AML) is a common benign mesenchymal tumour that is commonly seen in the kidney and other than this site is generally very rare. The Aim is to study the different testicular lesions and to search for the rare tumours of testis. Materials and methods: It is a Hospital based Prospective observational study over a period of 3 years in orchidectomy specimens. Sample size includes 100 cases. Results : Non neoplastic testicular lesions accounts for the majority of the cases with most commonly seen in second decade of life while the Neoplastic lesions seen mostly in the $3^{\text {rd }}$ and $4^{\text {th }}$ decades of life with encountering one rare case of Testicular Angiomyolipoma. Conclusion: Diagnosing rare tumours of any organ is always a challenging task for every pathologist and it is also a visual treat. Hence it is imperative to maintain hawks vigil during microscopic diagnosis to identify such rare tumours for better management strategies.

Keywords: Testis, Germ cell Tumour, Rare, Angiomyolipoma, Orchidectomy, Neoplastic.

Copyright @ 2020: This is an open-access article distributed under the terms of the Creative Commons Attribution license which permits unrestricted use, distribution, and reproduction in any medium for non-commercial use (NonCommercial, or CC-BY-NC) provided the original author and sources are credited.

\section{INTRODUCTION}

Testicular lesions are categorized as Non neoplastic lesions and Neoplastic lesions. Germ cell Tumours (GCT) of testis accounts for majority of the testicular tumours, and are the most prevalent solid malignancies in young adult males and represents $95 \%$ of all testicular cancers in men [1-3]. The GCTs are further divided into seminomas $(40-45 \%)$, Non Seminomatous tumours (approximately 40-45\%) and mixed germ cell tumours (approximately 10\%). Non germ cell tumours of testis are generally rare but subsequent histopathological analysis of all testicular specimens can sometimes reveal other testicular tumours of infrequent occurrence which constitutes just $5 \%$ of all testicular neoplasms and some of these include Lymphoma, Sertoli cell tumours and Leydig cell tumours [2, 3]. Angiomyolipoma (AML) is a common benign mesenchymal tumour that is commonly seen in the kidney and Angiomyolipoma other than this site is generally very rare and to our knowledge very few cases has been reported in the testis till date $[4,5]$. The present was undertaken to determine the frequency of different types of testicular lesions according to the age of patients and to search for the rare tumours of testis.

\section{MATERIAL AND METHODS}

It is a hospital based prospective observational study done in the Kamineni Institute of Medical Sciences, Narketpally, Telangana, India for a duration of 3 years from August 2015 to August 2018 on the orchidectomy specimens received in the histopathology department. A total of 100 cases were collected during this period. The gross specimens received were fixed in $10 \%$ neutral buffered formalin for overnight fixation. Next day morning, thorough gross examination of fixed specimen is done and salient features were noted down. The specimens are grossed by the pathologist and the sections are taken from the representative sites. These sections were further processed into automated tissue processor. After processing, sections are embedded in paraffin to make paraffin blocks. These blocks are then cut serially in three to five micron thickness using rotatory microtome to prepare slides. Slides are then stained with routine Hematoxylin and Eosin stain and then mounted with DPX. The histopathological slides were examined by two pathologists before the final diagnosis was made. 


\section{RESULTS}

Out of 100 cases studied, the Non Neoplastic testicular lesions constitute the majority accounting for $63 \%$ and Neoplastic Testicular lesions account for $37 \%$. Maximum percentage of Non neoplastic lesions were reported in the age group ranging from 11-20 years. Of all Non neoplastic lesions maximum number of cases diagnosed were Torsion testis accounting for $34.9 \%$ followed by Atrophic testis, Undescended testis, Non specific Epididymo orchitis (Table-1).

Table-1: Age Wise Distribution of Non Neoplastic Lesions of Testis

\begin{tabular}{|l|l|l|l|l|l|l|l|l|l|}
\hline \multirow{2}{*}{ Lesion } & \multicolumn{9}{|c|}{ Age distribution (in years) } \\
\cline { 2 - 11 } & $\mathbf{0 - 1 0}$ & $\mathbf{1 1 - 2 0}$ & $\mathbf{2 1 - 3 0}$ & $\mathbf{3 1 - 4 0}$ & $\mathbf{4 1 - 5 0}$ & $\mathbf{5 1 - 6 0}$ & $\mathbf{6 1 - 7 0}$ & $\mathbf{7 1 - 8 0}$ & Total \\
\hline Undescended testis & 3 & 7 & 0 & 0 & 0 & 0 & 0 & 0 & $10(15.8 \%)$ \\
\hline Torsion testis & 1 & 12 & 5 & 3 & 1 & 0 & 0 & 0 & $22(34.9 \%)$ \\
\hline Atrophic testis & 0 & 0 & 0 & 0 & 2 & 4 & 4 & 0 & $10(15.8 \%)$ \\
\hline Nonspecific epididymo orchitis & 0 & 3 & 0 & 2 & 1 & 1 & 1 & 2 & $10(15.8 \%)$ \\
\hline Testicular abscess & 0 & 0 & 0 & 1 & 2 & 0 & 0 & 0 & $3(4.7 \%)$ \\
\hline Tubercular epididymo orchitis & 0 & 3 & 0 & 3 & 0 & 1 & 1 & 0 & $8(12.6 \%)$ \\
\hline Total & $\mathbf{4}$ & $\mathbf{2 5}$ & $\mathbf{5}$ & $\mathbf{9}$ & $\mathbf{6}$ & $\mathbf{6}$ & $\mathbf{6}$ & $\mathbf{2}$ & 63 \\
\hline Percentage (\%) & $\mathbf{6 . 3}$ & $\mathbf{3 9 . 6}$ & $\mathbf{7 . 9}$ & $\mathbf{1 4 . 2}$ & $\mathbf{9 . 5}$ & $\mathbf{9 . 5}$ & $\mathbf{9 . 5}$ & $\mathbf{3 . 1}$ & \\
\hline
\end{tabular}

Out of all Neoplastic lesions of testis, maximum number of cases reported were Seminoma $(45.9 \%)$, followed by mixed germ cell tumors $(40.5 \%)$ as shown in Table-2 with most common age group involved in during third decade of life. The Microscopic features in all cases of seminoma reported were clusters and sheets of large round to polygonal shaped cells with clear cytoplasm, distinct cell borders, squared off nuclei and prominent nucleoli separated by fibrous septa infiltrated with lymphocytes (Figure-1).
In our study we also came across one rare Tumour Angiomyolipoma which is a common benign mesenchymal tumour that is commonly seen in the kidney and Angiomyolipoma other than this site is generally very rare and to our knowledge very few cases has been reported in the testis till date. Figure-2 shows the gross picture of Angiomyolipoma Testis with encapsulated solid grey tan to grey yellow mass. Microscopy revealed haphazard mature adipose tissue with myoid spindle cells and dysmorphic thick walled hyalinized blood vessels without elastic lamina (Figure$3)$.

Table-2: Age Wise Distribution of Neoplastic Lesions of Testis

\begin{tabular}{|l|l|l|l|l|l|l|l|l|l|}
\hline \multirow{2}{*}{ Lesion } & \multicolumn{9}{|c|}{ Age distribution (in years) } \\
\cline { 2 - 11 } & $\mathbf{0 - 1 0}$ & $\mathbf{1 1 - 2 0}$ & $\mathbf{2 1 - 3 0}$ & $\mathbf{3 1 - 4 0}$ & $\mathbf{4 1 - 5 0}$ & $\mathbf{5 1 - 6 0}$ & $\mathbf{6 1 - 7 0}$ & $\mathbf{7 1 - 8 0}$ & Total \\
\hline Seminoma & 0 & 0 & 10 & 5 & 2 & 0 & 0 & 0 & $17(45.9 \%)$ \\
\hline yolk sac tumor & 0 & 0 & 1 & 2 & 0 & 0 & 0 & 0 & $3(8.1 \%)$ \\
\hline Mixed germ cell tumors & 0 & 0 & 12 & 3 & 0 & 0 & 0 & 0 & $15(40.5 \%)$ \\
\hline Lymphoma & 0 & 0 & 0 & 0 & 0 & 1 & 0 & 0 & $1(2.7 \%)$ \\
\hline Angiomyolipoma & 0 & 0 & 0 & 0 & 0 & 1 & 0 & 0 & $1(2.7 \%)$ \\
\hline Total & $\mathbf{1}$ & $\mathbf{0}$ & $\mathbf{2 3}$ & $\mathbf{1 0}$ & $\mathbf{2}$ & $\mathbf{2}$ & $\mathbf{0}$ & $\mathbf{0}$ & $\mathbf{3 7}$ \\
\hline Percentage (\%) & $\mathbf{2 . 7}$ & $\mathbf{0}$ & $\mathbf{6 2 . 1}$ & $\mathbf{2 7}$ & $\mathbf{5 . 4}$ & $\mathbf{5 . 4}$ & $\mathbf{0}$ & $\mathbf{0}$ & \\
\hline
\end{tabular}

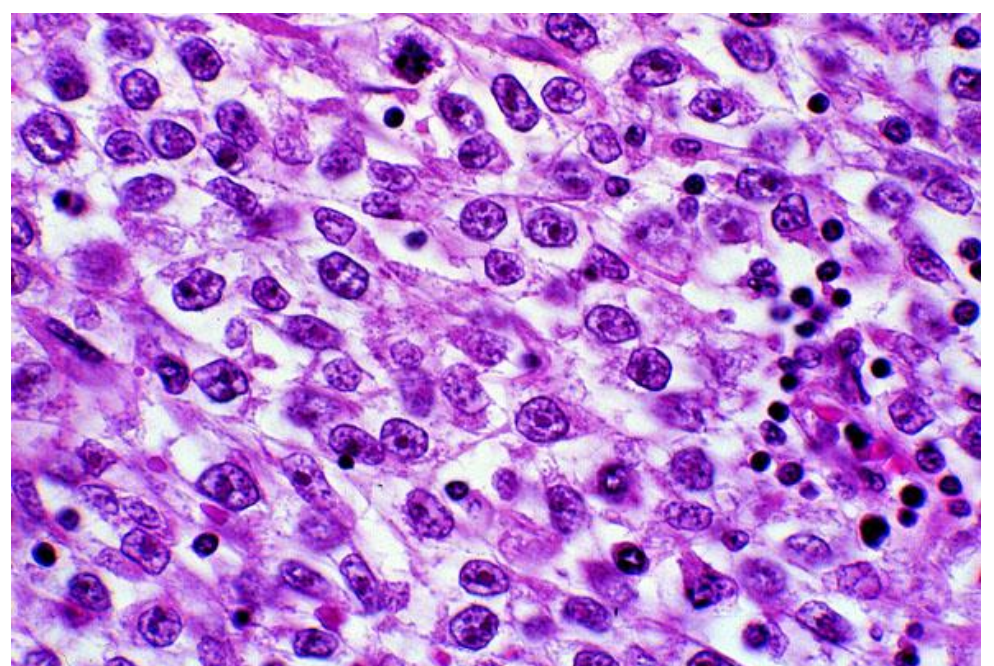

Fig-1: Seminoma. Note lymphocytes in septae in between lobules of round uniform cells with clear cytoplasm and central nuclei $(\mathrm{H} \& \mathrm{E}, 40 \mathrm{X})$ 

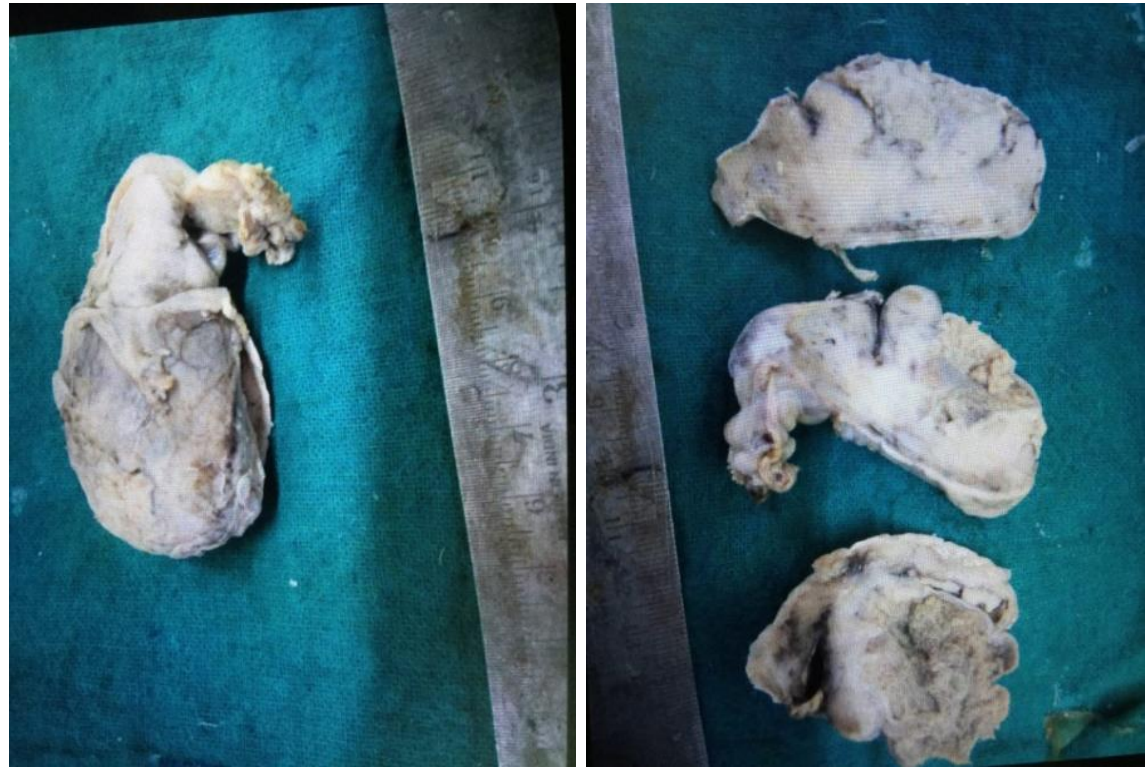

Fig-2: Angiomyolipoma. Gross picture showing solid encapsulated grey tan mass

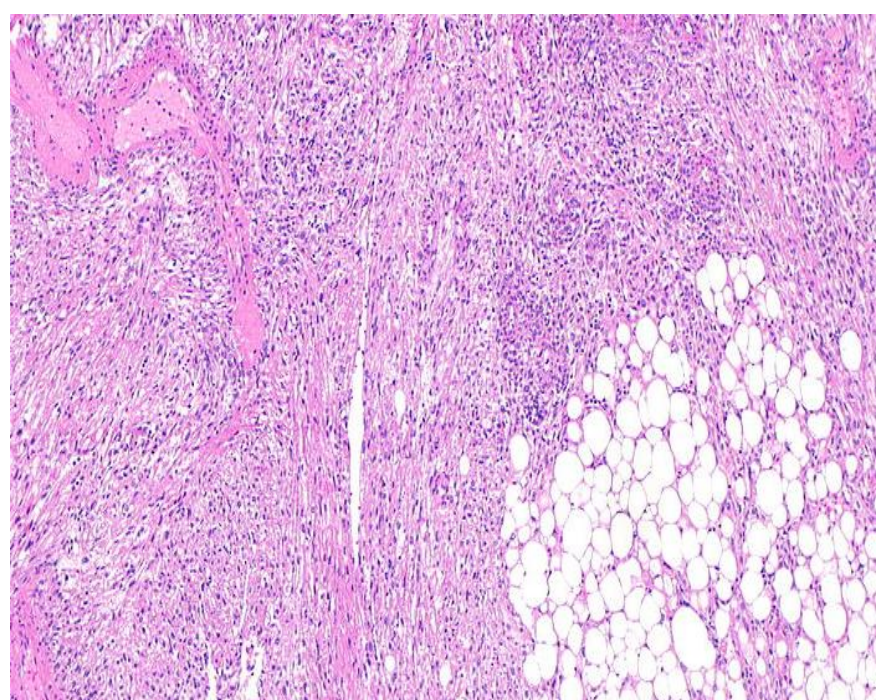

Fig-3: Angiomyolipoma. Haphazard mature adipose tissue, smooth muscles radiating from thick blood vessels (H\&E, 40X)

\section{DISCUSSION}

Though the incidence of testicular cancer is low, it is one of the commonest malignancies occurring in young adults with seminoma being commonest among the germ cell tumors especially in third decade of life. Various authors studied the incidence of benign and malignant lesions, which were compared with the present study. In the present study Non Neoplastic lesions constituted $63 \%$ while Neoplastic lesions constituted $37 \%$.

In our study the Non Neoplastic Testicular lesions were more common than the Neoplastic ones which is in concordance with Reddy $\mathrm{H}$, Patel MB and other studies [6-9]. Out of all Non Neoplastic lesions Torsion testis was most common constituted $34.9 \%$ which is in concordance with Reddy $\mathrm{H}$ and Patel $\mathrm{MB}$ studies (Table-3).

Table-3: Comparison of Histopathological types of Non Neoplastic Testicular lesions in various studies

\begin{tabular}{|c|c|c|c|c|}
\hline Lesion & $\begin{array}{l}\text { Present study } \\
\mathrm{N}=63\end{array}$ & $\begin{array}{l}\text { Abba K } \\
\{2016\} N=70\end{array}$ & $\begin{array}{l}\text { Reddy } H\{2016\} \\
N=86\end{array}$ & $\begin{array}{l}\text { Patel MB }\{2015\} \\
N=85\end{array}$ \\
\hline Undescended testis & $15.8 \%$ & $10 \%$ & $14 \%$ & $8.2 \%$ \\
\hline Torsion testis & $34.9 \%$ & $14.3 \%$ & $22.1 \%$ & $55.2 \%$ \\
\hline Atrophic testis & $15.8 \%$ & - & $19.8 \%$ & - \\
\hline Nonspecific epididymo orchitis & $15.8 \%$ & $10 \%$ & $3.5 \%$ & $9.4 \%$ \\
\hline Testicular abscess & $4.7 \%$ & $4.3 \%$ & $19.7 \%$ & $16.4 \%$ \\
\hline Tubercular epididymo orchitis & $12.6 \%$ & $12.9 \%$ & $3.5 \%$ & $9.4 \%$ \\
\hline
\end{tabular}


Among the Neoplastic Testicular lesions, seminoma was most common constituted $17 \%$ followed by mixed germ cell tumours which constituted $15 \%$ which are in concordance with the studies done by Chakrabarty PR, Reddy H, Patel MB (Table-4) [6-8]. We also reported one Rare case of Angiomyolipoma in a 45 year male patient who underwent orchidectomy for suspected testicular tumour clinically and radiologically which was not seen in the studies done by Chakrabarty PR, Reddy H, Patel MB [6-8] and only very few cases reported till date. Testicular angiomyolipoma is not officially listed in the world health organization histological typing of male testicular tumours.
Therefore, the diagnosis and treatment strategy for testicular angiomyolipoma has not been established [4, 5]. The tumour in the present case was composed of enlarged blood vessels, abundant medium to large adipose cells and foci of smooth muscle elements, which is compatible with testicular angiomyolipoma. However, the cellular origin of testicular angiomyolipoma remains unknown [5]. We also reported one rare case of Testicular Lymphoma in an elderly aged male which was also not reported in the study done by Chakrabarty PR, Reddy H, Patel MB [6$8]$.

Table-4: Comparison of Histopathological types of Neoplastic Testicular lesions in various studies

\begin{tabular}{|l|l|l|l|l|}
\hline Lesion & $\begin{array}{l}\text { Present study } \\
\mathbf{N}=37\end{array}$ & $\begin{array}{l}\text { Chakrabarty PR }\{\mathbf{2 0 1 6}\} \\
\mathbf{N}=37\end{array}$ & $\begin{array}{l}\text { Reddy H }\{2016\} \\
\text { N=14 }\end{array}$ & $\begin{array}{l}\text { Patel MB }\{2015\} \\
\text { N=15 }\end{array}$ \\
\hline Seminoma & $17 \%$ & 35.14 & $42.9 \%$ & $40 \%$ \\
\hline Yolk sac tumour & $3 \%$ & $2.7 \%$ & - & $6.6 \%$ \\
\hline Mixed germ cell tumours & $15 \%$ & $32.43 \%$ & $43 \%$ & - \\
\hline Angiomyolipoma & $1 \%$ & - & - & - \\
\hline Lymphoma & $1 \%$ & - & - & - \\
\hline
\end{tabular}

\section{CONCLUSION}

Testicular Tumors even though rare, The Incidence is slowly rising especially in the adolescent age groups. In our study Testicular tumors showed a varied histomorphology with reporting of one rare case of Testicular Angiomyolipoma. Diagnosing rare tumours of any organ is always a challenging task for every pathologist and it is also a visual treat Hence it is imperative to maintain hawks vigil during microscopic diagnosis to identify such rare tumours for better management strategies.

\section{REFERENCES}

1. Pratap, V. K., \& Agarwal, S. (1971). Testicular neoplasms. India Journal of cancer, 40-53.

2. Rosai, J. (2011). Male reproductive system. In: Rosai and Ackerman's Surgical Pathology. 10th ed. Vol 1. Elsevier: 1335-1336.

3. Kumar, V., Abbas, A. K., Fausto, N., \& Epstein, J. I. (2004). The lower urinary tract and male genital system. In: Robbins and Cotran Pathological basis of diseases. 7th ed. Saunders, 1039-41047.

4. Lane, T. M., Masood, J., Shah, N., Koye, B., \& Hill, J. (2004). Angiomyolipoma of the testis. Journal Urology, 171: 794.
5. Richie, J. P., \& Steele, G. S. Neoplasms of the testis. In: Walsh, P. C., Retik, A. B., Vaughan, E. D., \& Wein, A. J. (eds). (2001). Campbell's Urology, 8th edn. Saunders, Philadelphia, PA, 2876-919.

6. Reddy, H., Chawda, H., \& Dombale, V. D. (2016). Histomorphological analysis of testicular lesions. Indian Journal of Pathology and Oncology, 3(4);558-563.

7. Patel, M. B., Goswami, H. M., Parikh, U. R., \& Mehta, N. (2015). Histopathological study of testicular lesions. Gujarat Medical Journal, 70(1), 41-46.

8. Chakrabarti, P. R., Dosi, S., Varma, A., Kiyawat, P., Khare, G., \& Matreja, S. (2016). Histopathological trends of testicular neoplasm: An experience over a decade in a tertiary care centre in the Malwa belt of central India. Journal of clinical and diagnostic research: JCDR, 10(6), EC16- EC18.

9. Abba, K., Tahir, M. B., Dogo, H. M., \& Nggada, H. A. (2016). Testicular and paratesticular nonneoplastic lesions in university of Maiduguri teaching hospital: A 10-year retrospective review. Borno Med J, 13, 39-44. 